\title{
Effects of Removal of Extractives on the Chemical Composition and Mechanical Properties of Wood
}

\author{
Dongliang Zhao, ${ }^{\mathrm{a}, \mathrm{b}}$ Haibiao Yu, ${ }^{\mathrm{a}, \mathrm{b}}$ Xiuchun Bao, ${ }^{\mathrm{a}, \mathrm{b}}$ Jinwei Liu, ${ }^{\mathrm{a}, \mathrm{b}}$ Haoqiang Yuan, ${ }^{\mathrm{a}, \mathrm{b}}$ \\ Yan Wang, ${ }^{a, b}$ and Zhenhua Xue ${ }^{a, b, *}$
}

\begin{abstract}
Poplar and pine wood were extracted with water, $1 \% \mathrm{NaOH}$ (wt\%) solution, and benzene:ethanol solution $\left(\mathrm{V}_{1}: \mathrm{V}_{2}, 2: 1\right)$ to investigate the governing factors and mechanism by which extractives affect wood structure and mechanical properties. The structure, pore distribution, crystal structure, and mechanical properties of samples were analyzed by Fourier transform infrared spectroscopy (FTIR), adsorption of $\mathrm{N}_{2}$ gas, $\mathrm{X}$ ray diffraction $(\mathrm{XRD})$, and mechanical testing, respectively. The results demonstrated that cellulose, hemicellulose, and lignin were degraded to some extent in the course of the dissolution of the extractives. This degradation had a great influence on the structure and quantity of pores. The extraction treatment did not change the crystallization type of the wood, but it increased the crystallinity of the wood, and the length and width of the crystallization area changed. In addition, the mechanical properties of wood were changed when the content of the extractives was reduced.
\end{abstract}

Keywords: Wood; Extractive; Mechanical properties; Structure

Contact information: a: College of Material Science and Art Design, Inner Mongolia Agricultural University, Hohhot, 010018, China; b: Inner Mongolia Key Laboratory for Sand Shrubs Fibrosis and Energy Development and Utilization, Hohhot, 010018, China;

*Corresponding author: $x \_z h e n h u a @ 126 . c o m$

\section{INTRODUCTION}

Among wood materials, cellulose, hemicellulose, and lignin are the main structural components of different cell walls (Li et al. 2018). In its natural state, cellulose is a linear polymer with a degree of polymerization between 8000 and 15000 (Fang et al. 2017). Hemicellulose is a short-chain polymer with a degree of polymerization of 150 to 250, and more branched chains (Li et al. 2018). Lignin is a three-dimensional cross-linked polymer (Peng et al. 2017). However, the structure of hemicellulose and lignin will change with different tree species. Generally, wood biomass can be classified as either softwood or hardwood, depending on its lignocellulosic composition (hemicellulose, cellulose, lignin, and extractives) and shape (conifers and flowering plants) (Kim et al. 2016). The botanical difference between hardwood and softwood is mainly reflected in chemistry and structure (Yang et al. 2012). The acetylglucuronoxylan macromolecule of hardwood hemicellulose is generally composed of glucuronic acid, xylose molecules, and acetyl groups. Softwood hemicellulose is mainly composed of galactoglucomannan, accompanied by a small amount of glucomannan and arabinoglucuronoxylan (Li et al. 2013). Moreover, the xylose units are connected by $\beta-1,4$-glycosidic bonds to form the main molecular chain of hardwood hemicellulose, while the main molecular chain of softwood hemicellulose is mainly composed of mannose and glucose (Chaouch et al. 2013). In addition, although the lignin of hardwood and softwood are both three-dimensional cross-linked aromatic 
polymers composed of phenylpropane units, the structure of aromatic polymers in hardwood and softwood is different. Lignin in hardwood is composed of 3,5-dimethoxy4-hydroxyphenyl (syringyl) type and guaiacol type, while softwood lignin is 4-hydroxy-3methoxyphenyl (guaiacyl) type and a small amount of phydroxyphenyl type (Ding et al. 2017).

In hardwood and softwood, the respective structures of hemicellulose and lignin are not only different, some extractives but also are also different (Sheshmani et al. 2012). For example, pine (softwood) contains more oleophilic extractives (fats, fatty acids, waxes, monomeric compounds, and diterpenoids compounds, etc.) than poplar (hardwood) (Roffael 2016). The extractives contains many organic and inorganic substances (such as starch, tannins, pigments, pectins, fatty acids and gums, etc.), which are widely present in resin canals, gum canals, and parenchyma cells (Valette et al. 2017).

Although only a few percent of the extractives are present in wood, they have a significant effect on the mechanical properties and quality of wood (Pandey 2005). According to the current literature, the trend of the influence of the extractives on different mechanical properties of wood is different. Arganbright (1971) found that the modulus of rupture (MOR) was not affected when the redwood was extracted, while the modulus of elasticity (MOE) was increased with the decrease of the extractives content. Grabner et al. (2005) studied the effects of heartwood extractives on the lateral mechanical properties of larch plants. The results showed that the increase of the heartwood extractives content is closely related to the increase of the transverse compressive strength and Young's modulus. Hernandez (2007) extracted 9 kinds of tropical hardwoods and sugar maple by cold water, hot water, cyclohexane (CYC), acetone (ACE), and methanol (MET). They found that CYC and ACE had no effect on the compressive strength of wood, but other extracted components had an effect the compressive strength by changing the density of wood. Golpayegani et al. (2012) also observed that the dynamic elastic modulus of white mulberry was decreased after five polar solvents of extraction. Wang et al. (2016) carried out organic extraction treatment on the wood, and the hardness and elastic modulus of the cell wall showed a downward trend after extraction. Although in the existing literature there have been many studies on the effect of extractives dealing with the lateral mechanical properties of wood, there have been relatively few studies on the influence of the extractives on the longitudinal mechanical properties (such as tensile strength) of wood and impact properties. In addition, the cell wall polymer structures of hardwood and softwood are also different. Therefore, there is a need for a more complete understanding of difference between the effect of extractives on softwood and hardwood. In this study, poplar (hardwood) and pine (softwood), which are widely present in northern China, were studied as raw materials, and the effects of removal of the extractives on the chemical composition and mechanical properties of hardwood and softwood were considered.

\section{EXPERIMENTAL}

\section{Materials}

The poplar and pine wood were obtained from the factory of Inner Mongolia Agricultural University (Hohhot, China). The selected poplars (Populus L.) and pine (Pinus sylvestris L. var. mongholica Litv.) trees were more than 20 years old (main cutting age). A tree height of $2 \mathrm{~m}$ was the dividing point, and 1-m-long sample was taken (Fig. 
1a). Sapwood parts of poplar and pine were processed into 2-cm-thick plates along the radial direction of the trunk, and then the samples were sawn (Fig. 1b).

Benzene $\left(\mathrm{C}_{6} \mathrm{H}_{6}\right), 95 \%$ ethanol $\left(\mathrm{CH}_{3} \mathrm{CH}_{2} \mathrm{OH}\right)$, sodium hydroxide $(\mathrm{NaOH})$, nitric acid $\left(\mathrm{HNO}_{3}\right)$, sodium chlorite $\left(\mathrm{NaClO}_{2}\right)$, acetic acid $\left(\mathrm{C}_{2} \mathrm{H}_{4} \mathrm{O}_{2}\right)$, and sulfuric acid $\left(\mathrm{H}_{2} \mathrm{SO}_{4}\right)$ were obtained from Tianjin FengChuan Chemical Reagent Technology Co., Ltd. (Tianjing, China) and were analytically pure.

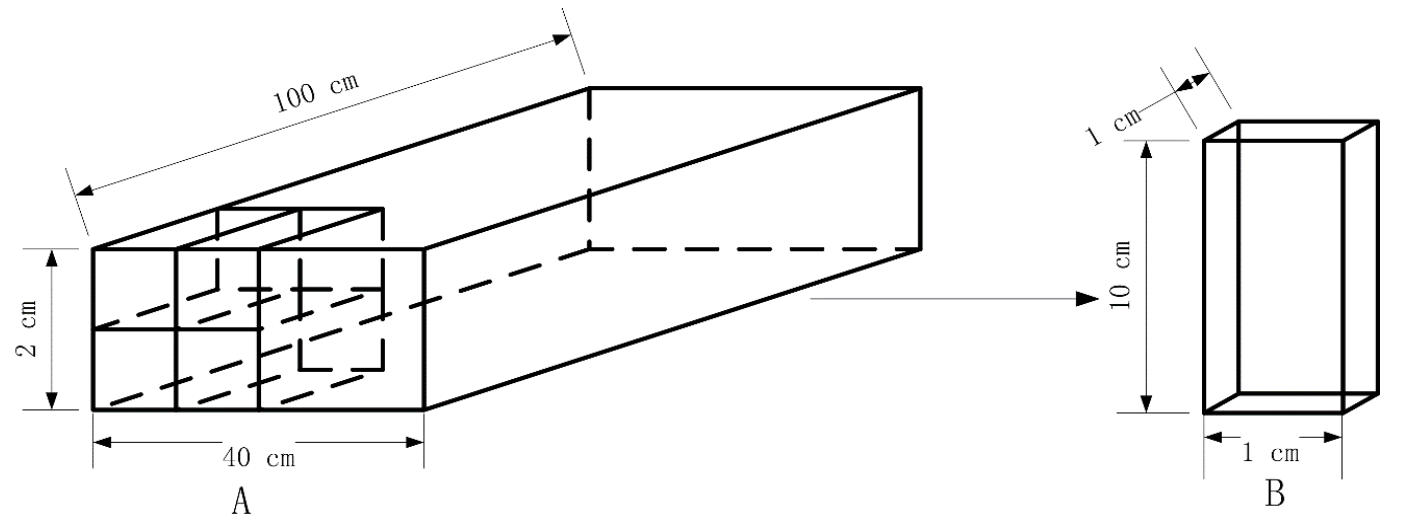

Fig. 1. Schematic diagrams of material selection: $(A)$ the locations of testing specimens, and (B) the test sample

\section{Methods}

Extraction process

According to the extraction process outlined in Table 1, the poplar and pine wood was extracted by a sequence with $\mathrm{H}_{2} \mathrm{O}, 1 \% \mathrm{NaOH}$ and benzene:ethanol solution $\left(\mathrm{V}_{1}: \mathrm{V}_{2}\right.$, 2:1). During extraction, each solvent was used sequentially and later replaced with another after washing the apparatus to avoid contamination. The time of each treatment step (water, $1 \% \mathrm{NaOH}$, benzene:ethanol $\left(\mathrm{V}_{1}: \mathrm{V}_{2}, 2: 1\right)$ solution) was $6 \mathrm{~h}$. Wood blocks of before and after the extraction treatment were air-dried at room temperature, and they were ground into fine powder with a pulverizer (Chongqing Ruiqianshun Pharmaceutical Equipment Co. LTD, China). The fine powder between 40 mesh and 60 mesh was selected, and finally it was dried by air blast drying box (Changzhou JintanJingda Instrument Manufacturing Co. LTD, China).

Table 1. Extraction Process

\begin{tabular}{|c|c|c|c|}
\hline Type & Temperature $\left({ }^{\circ} \mathrm{C}\right)$ & Time $(\mathrm{h})$ & Solid-liquid Ratio $\left(\mathrm{m}_{1}: \mathrm{m}_{2}\right)$ \\
\hline Poplar & 70 & 6 & $1: 20$ \\
\hline Pine & 80 & 6 & $1: 20$ \\
\hline
\end{tabular}

Determination of chemical composition content before and after extraction

Under the action of $\mathrm{H}_{2} \mathrm{O}, 1 \% \mathrm{NaOH}$, and benzene:ethanol solution $\left(\mathrm{V}_{1}: \mathrm{V}_{2}, 2: 1\right)$, the substances dissolved from the wood were not only extractives, but also cellulose, hemicellulose, and lignin. However, the amount of dissolved substances was unclear. Thus, a full chemical analysis of wood powder was done (TAPPI). By comparing the chemical component content of the wood before and after extraction, the loss amount of each chemical component in the extraction process could be obtained. Specific analysis methods are as follows: the contents of hemicellulose as per TAPPI T223 om-10 (2010), lignin as 
per TAPPI T222 om-11 (2011), and extractives as per TAPPI T204 om-97 (1997), TAPPI T212 om-12 (2012), and TAPPI T207 om-99 (1999) were determined. Cellulose content was determined using the Cross method (Herliyana et al. 2008).

\section{Characterization and Analysis}

Fourier transformed infrared spectra (FTIR) analysis

The samples before and after extraction were performed on a Tensor 27 FTIR spectrometer (Bruker Optics, Karlsruhe, Germany) and scanned from 400 to $4000 \mathrm{~cm}^{-1}$ at a resolution of $4 \mathrm{~cm}^{-1}$. The $\mathrm{KBr}$ pellets were prepared by mixing $1 \mathrm{mg}$ of each sample powder with $150 \mathrm{mg}$ of $\mathrm{KBr}$.

\section{Pore structure analysis}

Degassing pretreatment was carried out for each type wood sample under the conditions of temperature at $75^{\circ} \mathrm{C}$ and vacuum degree less than $6.67 \times 10^{-2} \mathrm{~Pa}$. The degassing pretreatment could remove impurities on the internal void surface of the wood, and ensure the accuracy of subsequent test results. The pore structures of the samples were characterized by Belsorp-MiniII (MicrotracBEL, Ōsaka, Japan) at $77 \mathrm{~K}$.

$X$-ray diffraction (XRD) analysis

The crystal structure and crystallinity index (CrI) of each sample was investigated using a D8advance X-ray diffractometer (Bruker-AXS, Karlsruhe, Germany) with $\mathrm{Cu} \mathrm{K} \alpha$ radiation at voltage $V=40 \mathrm{kV}$ in the range $2 \theta=5^{\circ}$ to $90^{\circ}$ at a speed of $10^{\circ} / \mathrm{min}$.

Equation 1 (Segal et al. 1959) was used to calculate the crystallinity index (CrI) of samples from the $\mathrm{X}$-ray diffraction pattern,

$$
X=\left[\frac{I_{002}-I_{\mathrm{am}}}{I_{002}}\right] \times 100 \%
$$

where $I_{002}$ is the diffracted intensity of the crystalline segments at the peak around $2 \theta=22^{\circ}$ and $I_{\mathrm{am}}$ is the diffracted intensity of the amorphous regions at around $2 \theta=18^{\circ}$.

\section{Length and width of crystalline area analysis}

The half-width of the diffraction peak was obtained according to the X-ray diffraction pattern, and Eq. 2 (Patterson 1939) calculated the length and width of the crystalline area,

$$
D=\frac{K \lambda}{B_{\mathrm{hkl}} \cos \theta}
$$

where $D$ is the length or width of the crystalline area $(\mathrm{nm}), K=0.9$ is a constant, $\lambda=0.154$ $\mathrm{nm}$ is the wavelength of the incident X-ray, $\theta$ is the diffraction angle $\left(^{\circ}\right)$, and $B \mathrm{hkl}$ is the half-width of the diffraction peak in the X-ray diffraction pattern (radian). The length of the crystal region was calculated as half-width of the diffraction peak of (040). In addition, the width of the crystal region was calculated as half-width of the diffraction peak on the surface of (002).

\section{Mechanical properties analysis}

The tensile strength, bending strength, and toughness of the samples were tested by an AG-IC mechanical testing machine (Shimadzu, Kyoto, Japan), WDW-20A testing machine (Jinan Tianchen Machine Manufacturing Co., Ltd., Jinan, China), and a ZBC7000-B impact testing machine (Jinjian Instrument Co., Ltd., Jinan, China). The 
mechanical property dates were calculated according to the specific strength (strength/ density).

\section{RESULTS AND DISCUSSION}

\section{Chemical Composition Loss Rate Analysis}

The chemical composition and contents of pine and poplar wood before and after extraction were determined, and the results are shown in Fig. 2. It can be seen that the content of cellulose and hemicellulose of poplar was higher than that of pine, while the content of lignin was lower than that of pine. This is consistent with the conclusion drawn by He et al. (2019). Rigual et al. (2018) concluded in the study that the extractives content of softwood was higher than that of hardwood. However, the phenomenon shown in Fig. 2 is opposite. This may be related to the wood growth environment and tree species.
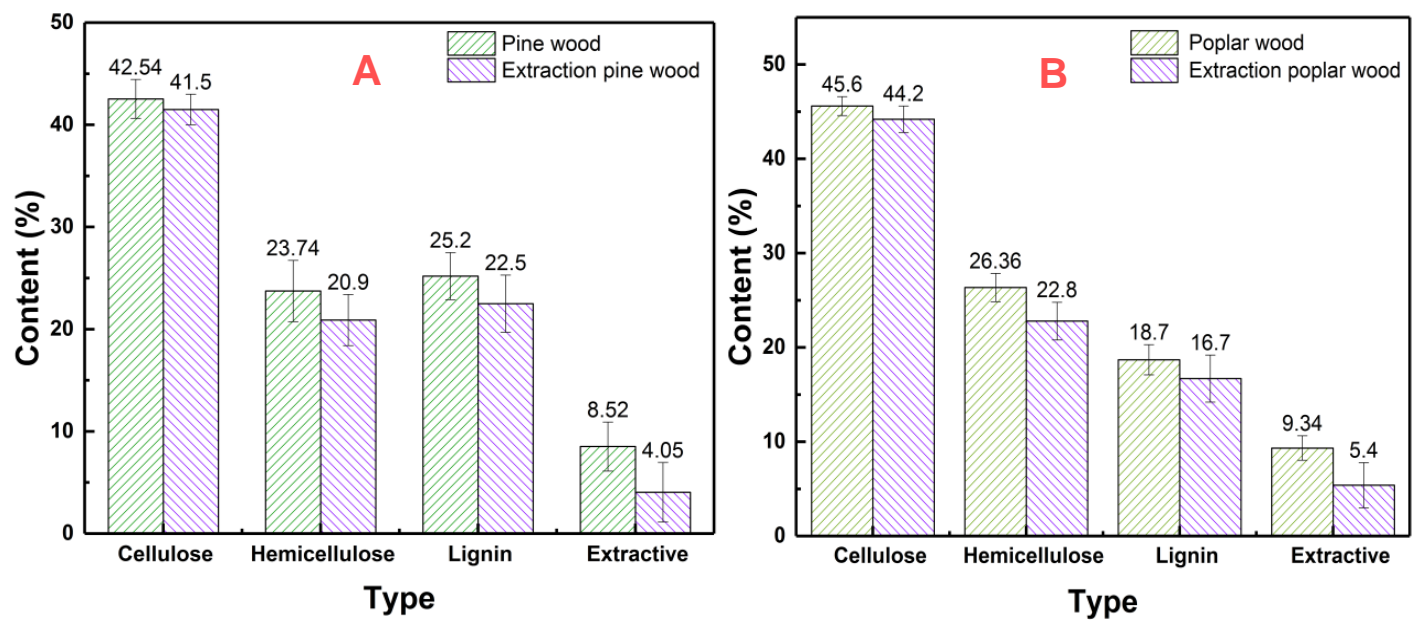

Fig. 2. Diagram of chemical composition content of pine wood (A) and poplar wood (B) before and after extraction.

Moreover, the differences in the degradation of cellulose, hemicellulose, and lignin between hardwood and softwood during the extraction process are discussed. Figure 2 shows that the cellulose, hemicellulose, and lignin of pine and poplar were degraded to different degrees after extraction treatment. Hemicellulose is an amorphous structure with many active groups and strong chemical activity, which is prone to be degraded in water and alkali solution. Therefore, during the extraction process, the loss of hemicellulose content of pine and poplar was $2.84 \%$ and $3.56 \%$, respectively. Because the xylan unit of hardwood acetylglucuronoxylan has more acetyl groups, the degradation effect in hot water is more obvious, and more acetic acid is generated (Golpayegani et al. 2012). Therefore, the hemicellulose of poplar wood is more degraded in the extraction process.

Cellulose is degraded due to the influence of acetic acid and $\mathrm{NaOH}$ solution in the extraction process (Bali et al. 2015), and the cellulose content of pine and poplar lost was $1.04 \%$ and $1.4 \%$. As poplar hemicellulose produces more acetic acid in hot water, the degradation of cellulose was more obvious. Therefore, the cellulose of poplar wood was more degraded than pine during the extraction process. 
In addition, lignin is degraded by acetic acid, $\mathrm{NaOH}$ solution and benzene:ethanol (2:1) solution (Sameni et al. 2017). Thus, during the extraction process, the loss of lignin content of pine and poplar was $2.7 \%$ and $2 \%$, respectively. Moreover, during the extraction process, the loss ratio of extractives of pine and poplar was $4.47 \%$ and $3.94 \%$, respectively. The reason why there was less degradation of the lignin of poplar and extractives in the extraction treatment may be related to the lower temperature of extraction treatment of poplar.

\section{FTIR Spectroscopy Analysis}

The FTIR spectra of samples before and after extraction are presented in Fig. 3. After extraction treatment of pine and poplar, the peak position of the hydroxyl association peak at $3342 \mathrm{~cm}^{-1}$ shifted to a higher position, and the peak intensity increased, which formed a sharp absorption peak (Sugii et al. 2017). This occurred because the hydroxyl group is in the free state, and the absorption peak is located at a higher position (3610 to $3640 \mathrm{~cm}^{-1}$ ) (Dandrea et al. 2008).
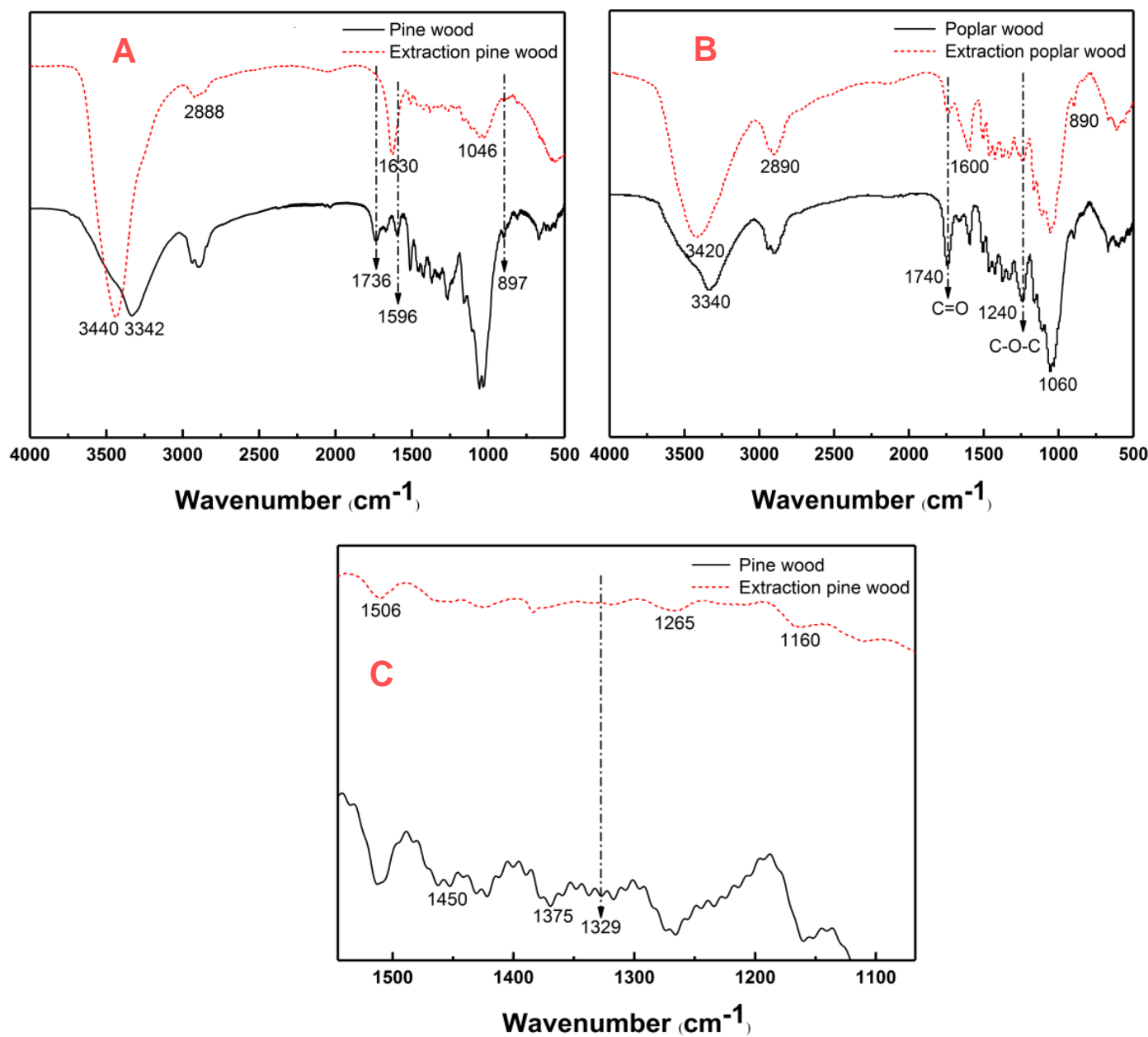

Fig. 3. Diagram of FTIR spectrum of pine wood $(A)(C$ is $A$ local enlargement of $A)$ and poplar wood $(B)$ before and after extraction

With the formation of hydrogen bonds, the absorption peak moves to the lower position and the band widens (Ishimaru et al. 2007). This indicates that the extraction treatment reduces the degree of wood hydroxyl association and then the number of free 
hydroxyls is increased. Figure 3A shows that the strength of $\mathrm{C}-\mathrm{H}$ stretching vibration absorption peak $\left(2888 \mathrm{~cm}^{-1}\right)$ in methyl and methylene groups $\left(\mathrm{CH}_{3}\right.$ and $\left.\mathrm{CH}_{2}\right)$ of pine after extraction treatment was slightly reduced, but the position of the peak remained unchanged. The $\mathrm{C}=\mathrm{O}$ absorption peak of non-conjugate aldehydes, ketones, carbonyl groups, acyl groups, esters at $1736 \mathrm{~cm}^{-1}$, and the $\mathrm{N}-\mathrm{H}$ absorption peak of amide at $1596 \mathrm{~cm}^{-1}$ were eliminated after extraction. In addition, $\mathrm{C}=\mathrm{O}$ absorption peaks in conjugate aldehydes, ketones, carbonyl groups, acyl groups, and esters appeared at $1630 \mathrm{~cm}^{-1}$ (Huang et al. 2008). Furthermore, the $\mathrm{C}-\mathrm{O}$ of the saturated fatty ether was destroyed, resulting in a decrease of the intensity of the absorption peak $\left(1046 \mathrm{~cm}^{-1}\right)$. In Fig. 3B, the absorption peak at $2890 \mathrm{~cm}^{-1}$ was unchanged. The $\mathrm{C}=\mathrm{O}$ absorption peak intensity of the non-conjugated aldehydes, ketones, carbonyls, acyl groups, and esters at $1740 \mathrm{~cm}^{-1}$ was weakened, but the intensity of the $\mathrm{N}-\mathrm{H}$ absorption peak at $1600 \mathrm{~cm}^{-1}$ was increased (Ufodike et al. 2020).

In Fig. 3C, the vibration absorption peak of benzene ring skeleton $\left(1450 \mathrm{~cm}^{-1}, 1506\right.$ $\left.\mathrm{cm}^{-1}\right)$, the C-H absorption peak of aliphatic methyl and ether hydroxyl $\left(1375 \mathrm{~cm}^{-1}\right)$, the $\mathrm{N}=\mathrm{O}$ absorption peak of nitro group $\left(1329 \mathrm{~cm}^{-1}\right)$, the C-O-C absorption peak of phenolic ether bond $\left(1265 \mathrm{~cm}^{-1}\right)$, and symmetrical C-O-C bridge stretching $\left(1160 \mathrm{~cm}^{-1}\right)$ were all reduced (Hu et al. 2020). This was caused by the solvent dissolving esters, ethers, alcohols, and some sugars in the wood extractive. Structural changes of poplar were similar to the above during the extraction process (Fig. 3B), but the variation degree of each chemical bond was small. Alternatively, the intensity of characteristic absorption peaks of cellulose and hemicellulose $\left(1200 \mathrm{~cm}^{-1}\right.$, and $\left.1120 \mathrm{~cm}^{-1}\right)$ and the characteristic absorption peaks of lignin $\left(1506 \mathrm{~cm}^{-1}, 1270 \mathrm{~cm}^{-1}\right)$ were reduced.

Table 2. The FTIR Bands of Wood

\begin{tabular}{|c|c|c|}
\hline $\begin{array}{l}\text { Wavenumber of Pine Wood } \\
\qquad\left(\mathrm{cm}^{-1}\right)\end{array}$ & $\begin{array}{l}\text { Wavenumber of Poplar } \\
\text { Wood }\left(\mathrm{cm}^{-1}\right)\end{array}$ & Functional Groups \\
\hline 3342 & 3340 & $\mathrm{OH}$ \\
\hline 2888 & 2890 & $\mathrm{CH}_{3}-\mathrm{CH}_{2-}$ (cellulose) \\
\hline 1736 & 1740 & $\mathrm{C}=\mathrm{O}$ (non-conjugate) \\
\hline 1630 & & $\mathrm{C}=\mathrm{O}$ (conjugate) \\
\hline 1596 & 1600 & $\mathrm{~N}-\mathrm{H}$ (amide) \\
\hline 1450,1506 & 1450,1506 & $\begin{array}{c}\text { A benzene ring skeleton } \\
\text { (lignin) }\end{array}$ \\
\hline 1375 & 1375 & $\begin{array}{l}\text { C-H (aliphatic methyl and ether } \\
\text { hydroxyl) }\end{array}$ \\
\hline 1329 & 1329 & $\mathrm{~N}=\mathrm{O}$ (nitro group) \\
\hline 1265 & 1240 & C-O-C (phenolic ether bond) \\
\hline 1160 & 1160 & $\begin{array}{c}\text { Symmetrical C-O-C bridge } \\
\text { stretching }\end{array}$ \\
\hline 1046 & 1060 & $\mathrm{C}-\mathrm{O}$ (saturated fatty ether) \\
\hline 897 & 890 & $\beta$-glycosidic linkages \\
\hline
\end{tabular}

\section{Pore Structure Analysis}

To clarify the influence of loss of the extractives on the pore structure of wood, the authors conducted a nitrogen adsorption and desorption experiment, and the obtained nitrogen adsorption-desorption isotherms are shown in Fig 4. According to the classification of nitrogen adsorption-desorption isotherms by the International Union of Pure and Applied Chemistry (IUPAC) (Sing 1985), the nitrogen adsorption-desorption isotherms of poplar and pine before and after extraction treatment in Fig. 4 belonged to type IV isotherms. In the area where the relative pressure was low, the adsorption capacity 
increased rapidly. In this stage, the single-molecular layer adsorption and the filling of wood micropores were mainly completed. When the relative pressure was higher than 0.2 , the adsorption capacity increased slowly, which was mainly caused by the filling of mesopores and the adsorption of multi-molecular layers. As shown in Fig. 4, when the relative pressure exceeded 0.8 , the adsorption capacity increased rapidly again, and the adsorption was mainly accomplished through macropores in this stage. Figure 4A shows that the adsorption capacity of extracted pine was remarkably higher than that of unextracted pine. In the macroporous adsorption stage where the relative pressure was higher than 0.8 , the increase of adsorption capacity was most obvious. Thus, the extraction treatment increased the number of mesopores and macropores of pine wood. The difference from the above was that the extraction treatment had no effect on the adsorption of poplar in the micropore and mesopore stages, but the adsorption amount of poplar was obviously increased in the macropore adsorption stage. Therefore, only the number of macropores increased after poplar was extracted. According to IUPAC classification of hysteresis loops, the hysteresis loops of nitrogen adsorption-desorption isotherms of poplar and pine before and after extraction were $\mathrm{H}_{3}$ type. The shape of hysteresis loop was relatively long and narrow, which reflected that the pores in the sample have a flat slit structure.
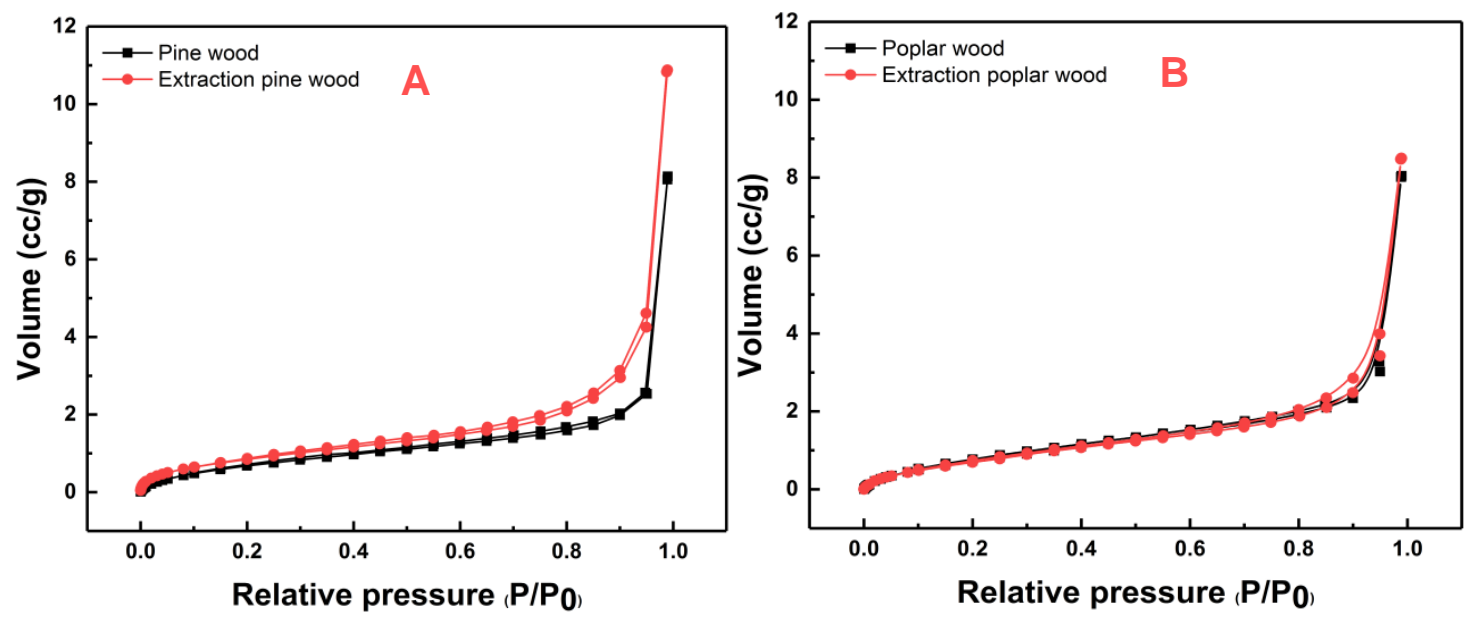

Fig. 4. Nitrogen adsorption-desorption isotherms of pine wood (A) and poplar wood (B) before and after extraction

According to the $\mathrm{BJH}$ principle, the nitrogen adsorption was calculated to obtain the distribution curve of mesopore diameter of wood sample, as shown in Fig. 5. According to the classification of IUPAC, the mesopore structure with a pore size of 2 to $50 \mathrm{~nm}$ in wood samples mainly corresponds to the pores in the cell wall. The pores in the cell wall were mainly produced between microfibrils and filling materials (lignin, hemicellulose, and extractives). Figure 5A shows that there were a large number of pore structures with the pore size of 3 to $5 \mathrm{~nm}$ in pine. After extraction treatment, chemical components such as extractives in pine were degraded at different levels. As a result, a large number of pores with the pore diameter of $3.06 \mathrm{~nm}$ and $5.6 \mathrm{~nm}$ were generated in the extraction of pine, and the curve strength within a pore diameter greater than $5.6 \mathrm{~nm}$ was higher than that of untreated pine. As shown in Fig. 5B, poplar was similar to pine, and it had a large number of pore structures with the diameter of 3 to $5 \mathrm{~nm}$. Although two new peaks appeared at 4.9 $\mathrm{nm}$ and $6.5 \mathrm{~nm}$ after the extraction of poplar, the intensity of overall diameter of pore 
distribution curve was lower than that of poplar without extraction. This is because the volume shrinkage of poplar after extraction results in a decrease in the number of pores (mesopores) in the cell wall. The above results showed that the loss of chemical components such as extractives had a significant effect on the pore quantity of wood.
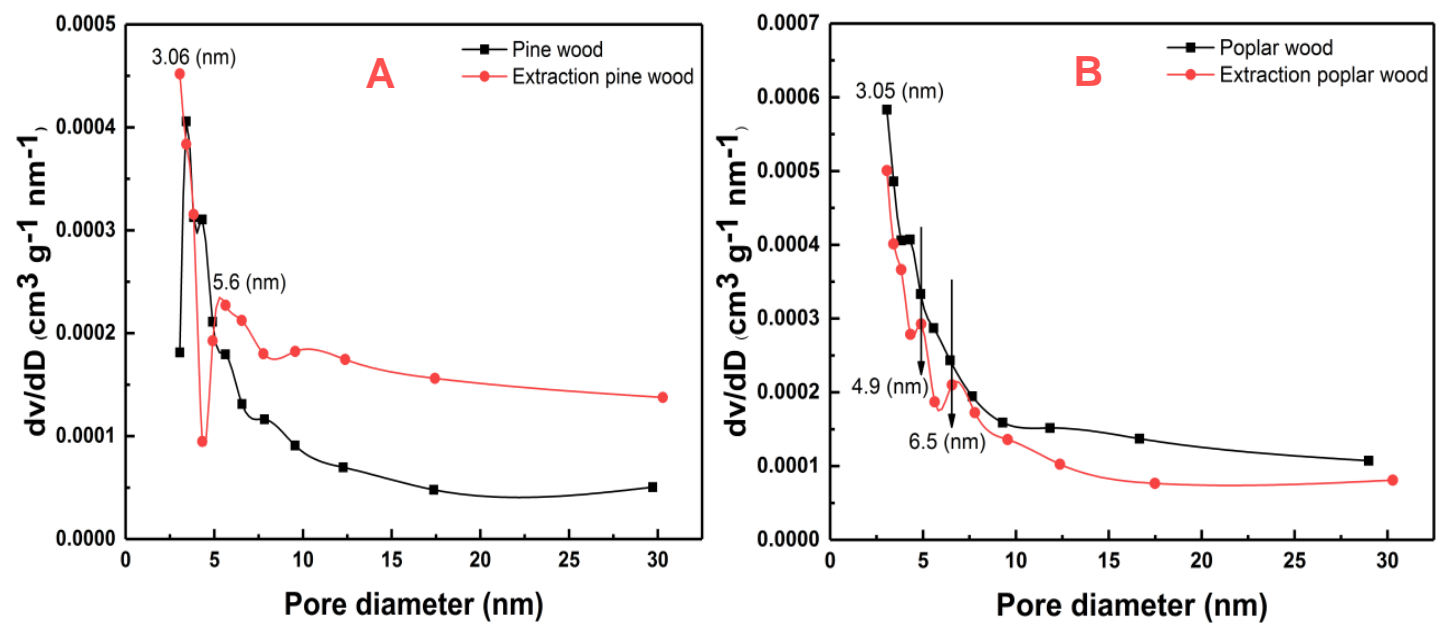

Fig. 5. Pore-size distribution curves of pine wood (A) and poplar wood (B) before and after extraction

\section{XRD Analysis}

To elucidate the structural changes caused by extraction treatment, X-ray diffraction analysis was conducted, as shown in Fig. 6. The position of the (002) diffraction peak did not change after the wood extraction treatment, and it indicated that the crystal type of cellulose did not change.
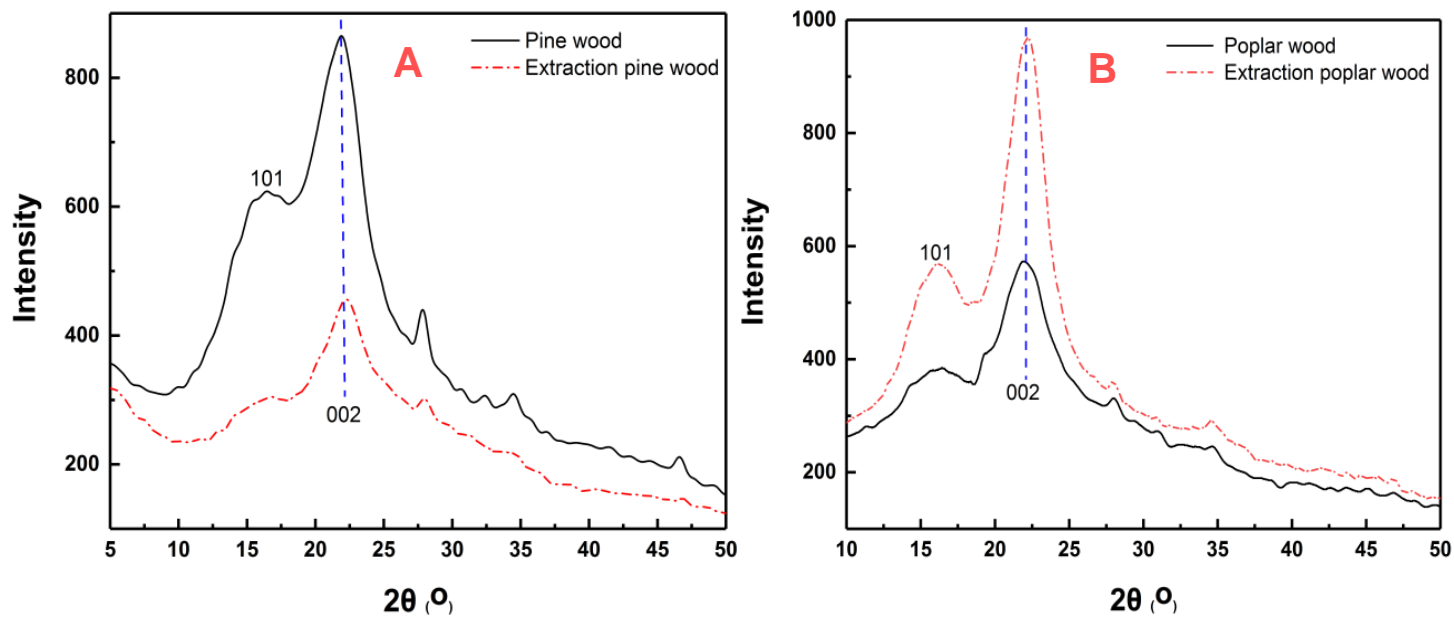

Fig. 6. XRD patterns of pine wood (A) and poplar wood (B) before and after extraction

After poplar and pine were extracted, the length of crystalline area was reduced $0.14 \mathrm{~nm}$ and $0.25 \mathrm{~nm}$ (Table 3), respectively, and the width of the crystalline area was reduced $0.09 \mathrm{~nm}$ (extraction of pine). This was caused by the destruction of the crystalline area during the peeling reaction of cellulose under the action of $\mathrm{NaOH}$. In contrast, the width of crystalline area of extraction poplar wood was increased $0.62 \mathrm{~nm}$ (Table 3). This 
may be caused by hydrogen bonding between the crystalline regions of microfibers and the cellulose molecular chains of adjacent microfibers. However, Fig. 3B shows a decrease in the number of hydrogen bonds, which may be caused by an increase in the number of free hydroxyl groups of hemicellulose and lignin degradation, and masks the increase in the number of hydrogen bonds. In addition, after extraction, the relative crystallinity of poplar and pine was increased $12.4 \%$ and $5.7 \%$, respectively. To sum up, the dissolution of extract had a certain effect on the crystal structure of wood.

Table 3. Main Parameters of Crystallization Area

\begin{tabular}{|c|c|c|c|}
\hline Type & $\begin{array}{c}\text { Crystallinity } \\
(\%)\end{array}$ & $\begin{array}{c}\text { Length of Crystalline } \\
\text { Area }(\mathrm{nm})\end{array}$ & $\begin{array}{c}\text { Width of Crystalline } \\
\text { Area }(\mathrm{nm})\end{array}$ \\
\hline Poplar Wood & 36.5 & 13.59 & 2.63 \\
\hline Extraction Poplar Wood & 48.9 & 13.45 & 3.25 \\
\hline Pine Wood & 31.2 & 12 & 2.73 \\
\hline Extraction Pine Wood & 34.9 & 11.75 & 2.64 \\
\hline
\end{tabular}

\section{Proposed Mechanism of Wood Extraction Treatment}

Figure 7 shows the proposed mechanism of structural change in wood during extraction. When wood is extracted with hot water, $1 \% \mathrm{NaOH}$ and benzene:ethanol $(2: 1)$ solution, in addition to dissolving the extractives, cellulose, hemicellulose, and lignin will inevitably be affected (Fig. 2). When impregnated with hot water, extractives (starch, lowmolecular sugar, tannin and gum) are dissolved, and a hydrolysis reaction happens about hemicellulose (Fatrawana et al. 2019). The acetyl groups on the hemicellulose molecular chain are dissolved in water to generate organic acid (mainly acetic acid). The production of this organic acid promotes the degradation of cellulose and lignin in water (Paredes et al. 2017).

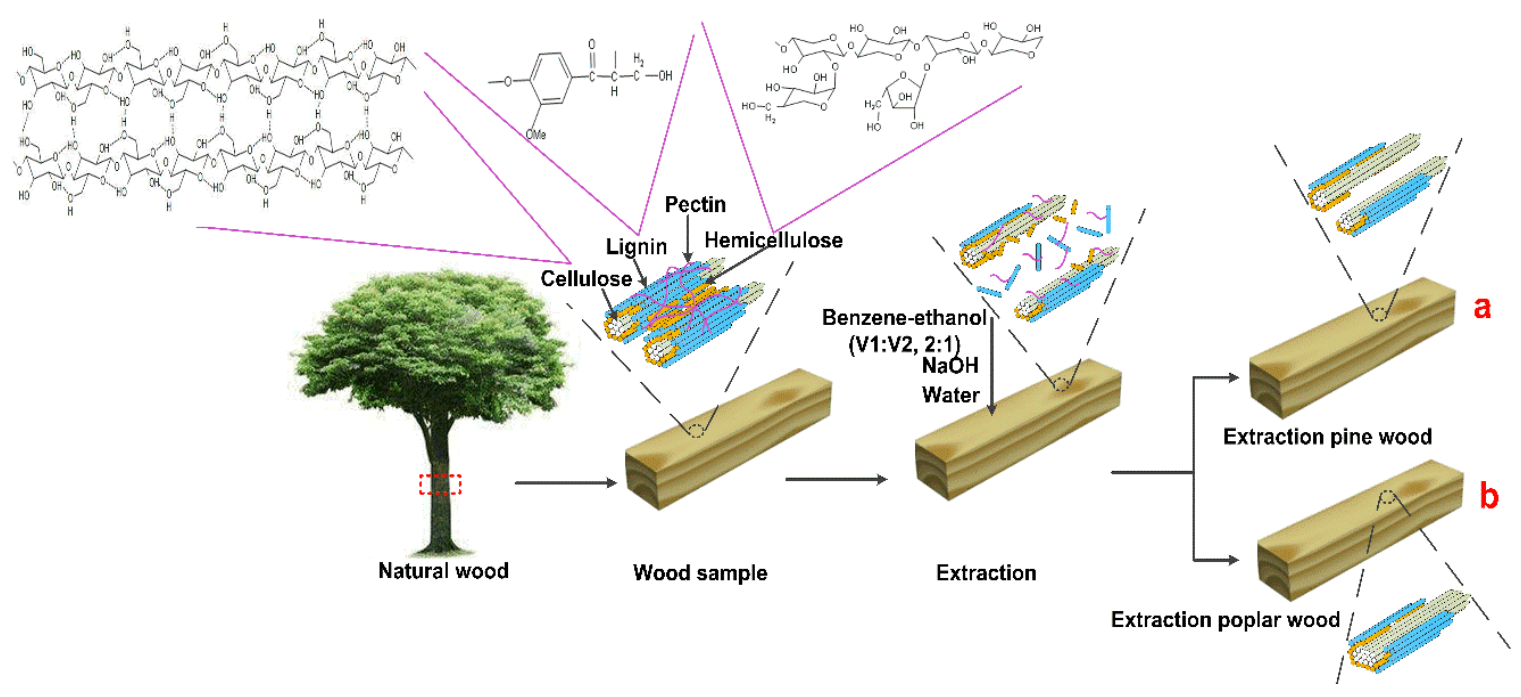

Fig. 7. Schematic diagram of extraction treatment of wood

In the $1 \% \mathrm{NaOH}$ solution, a part of the lipid extractives in the wood are saponified to generate some hydrophilic substances, such as alcohols and carboxylates. Then, they are dissolved in the solvent (the absorption peak at $1160 \mathrm{~cm}^{-1}$ in Fig. 3 is reduced) (Tao et al. 2010). In addition, the peeling reaction of cellulose and hemicellulose occurs in the alkaline solution, and the $\beta$-1,4-glycosidic bond between the sugar groups is broken (the absorption 
peak at $897 \mathrm{~cm}^{-1}$ in Fig. 3 is reduced), resulting in the loss of the end groups on the molecular chain. However, the peeling reaction will not go on forever. When the reducing end groups are converted into skewed sugar acid groups and there were no aldehyde groups, the peeling reaction will be terminated (Pei et al. 2017). It is worth noting that due to the low treatment temperature of wood in this study, only those hemicelluloses that are not closely associated with other wood constituents (cellulose and lignin) are solubilised by the alkaline solution (Doczekalska and Zborowska 2010). Therefore, a small proportion of cellulose and hemicellulose are degraded in alkali solution. For lignin, the phenolic hydroxyl group on the structural unit of macromolecular propane easily dehydrogenated in a high-concentration strong alkali solution, which induces the breaking of the $\alpha$-ether bond ( $\alpha$-aryl ether bond, $\alpha$-alkyl ether bond) (Pei et al. 2017). However, the concentration of $\mathrm{NaOH}$ in this study was only $1 \%$, and the temperature was low. Moreover, Ma et al. (2015) believed that the lignin in plant cell walls was embedded in the polysaccharide network, forming a close physical and chemical connection with polysaccharides, preventing solvent attack. Therefore, only a small amount of lignin was dissolved in $1 \% \mathrm{NaOH}$ solution.

The ethanol seeps into the wood and dissolves small molecules of sugar and tannins. However, ethanol has no solubility for polyphenols. In addition, benzene can penetrate into the wood structure and dissolves extractives such as lipids, waxes, and fatty acids (Doczekalska and Zborowska 2010). Therefore, in this study, benzene and ethanol were combined to treat wood at a ratio of $2: 1$. The $\beta-\mathrm{O}-4$ bond in lignin is broken by the use of benzene:ethanol, resulting in the dissolution of low molecular weight of lignin in solvents (Ma et al. 2014). Shi et al. (2019) also reached a similar conclusion in his research.

In addition, the above reactions will lead to the dissolution of amorphous materials (hemicellulose and extractive, etc.). Therefore, the proportion of the amorphous area decreases, the acreage of crystalline area relatively increases, and the relative crystallinity increases (Table 3) (Durmaz et al. 2019). The dissolution of internal components of wood (hemicellulose and extractives, etc.) will also increase the number of pores. However, the poplar after extraction shows a different trend (Fig. 7b). This is because during the process of drying, the microfibrils are close to each other to form hydrogen bonds when the moisture in the pores of the extracted poplar is moved outward. The pores are compressed and the diameter of pores becomes smaller or disappears. Therefore, the width of the crystalline region of poplar wood is increased after extraction, and the structure of the crystalline region is affected. However, the above structural changes do not occur during the drying process of pine after extraction (Fig. 7a). Therefore, the size of the crystalline zone after extraction pine is unchanged, the crystalline structure has not changed, and the number of pores has increased.

In summary, dissolution of chemical components (extractives and hemicellulose) can increase the number of pores in poplar and pine, but it does not affect the size and structure of the crystallization zone.

\section{Mechanical Properties Analysis}

Analysis of the influence of extractive on the mechanical properties of pine wood

It can be seen from Table 4 that the density of pine after extraction was reduced by $0.108 \mathrm{~g} / \mathrm{cm}^{3}$. This is because during the extraction process, the filler materials (extractives and hemicellulose, etc.) of pine are partially dissolved, causing the increase of pores in the cell wall (Fig. 5A). What's more, the pine wood after extraction did not shrink in volume. Therefore, the density was reduced (Vital et al. 1983). Regarding the change in wood 
density, similar results were reported by Durmaz et al. (2019). He deems that the removal of volatile extracts and moisture in the wood will cause the decrease of density.

Table 4. Mechanical Properties of Pine Wood Before and After Extraction

\begin{tabular}{|c|c|c|c|c|c|c|c|}
\hline Group & $\begin{array}{c}\text { Density } \\
\left(\mathrm{g} / \mathrm{cm}^{3}\right)\end{array}$ & \multicolumn{2}{|c|}{$\begin{array}{c}\text { Bending Strength } \\
(\mathrm{N} \cdot \mathrm{m} / \mathrm{Kg})\end{array}$} & \multicolumn{2}{c|}{$\begin{array}{c}\text { Tensile Strength } \\
(\mathrm{N} \cdot \mathrm{m} / \mathrm{Kg})\end{array}$} & \multicolumn{2}{c|}{$\begin{array}{c}\text { Impact Strength } \\
(\mathrm{N} \cdot \mathrm{m} / \mathrm{Kg})\end{array}$} \\
\hline & & Average & $\begin{array}{l}\text { Variable } \\
\text { Quantity }\end{array}$ & Average & $\begin{array}{l}\text { Variable } \\
\text { Quantity }\end{array}$ & Average & $\begin{array}{c}\text { Variable } \\
\text { Quantity }\end{array}$ \\
\hline Pine Wood & 0.548 & 180.35 & & 62.57 & & 61.82 & \\
\hline $\begin{array}{c}\text { Extraction } \\
\text { Pine Wood }\end{array}$ & 0.44 & 177.80 & -2.55 & 48.19 & -14.38 & 49.09 & -12.73 \\
\hline
\end{tabular}

In this study, the bending strength, tensile strength and impact strength of pine after extraction treatment were reduced by $2.55 \mathrm{~N} \cdot \mathrm{m} / \mathrm{Kg}, 14.38 \mathrm{~N} \cdot \mathrm{m} / \mathrm{Kg}$, and $12.73 \mathrm{~N} \cdot \mathrm{m} / \mathrm{Kg}$, respectively. When Missanjo and Matsumura (2016) studied the relationship between wood density and mechanical properties, they found that wood density had a significant positive correlation with bending strength. In addition, Wetzig et al. (2011) reported that wood density had an important effect on tensile strength, and the strength was increased with the increase of density. Therefore, the change in tensile strength and bending strength of pine wood after extraction was mainly caused by the change of density. As for the reason why the impact strength of pine wood is decreased after extraction, it is because relatively flexible substances (extractives and hemicellulose, etc.) are partially dissolved, the flexibility of wood is decreased, and the brittleness is increased.

\section{Analysis of the influence of extractive on the mechanical properties of poplar wood}

According to the research conclusions of Vital et al. (1983) and Durmaz et al. (2019), it can be known that the degradation of wood chemical components will lead to decrease of wood density. Surprisingly, the fillings materials (extractives and hemicellulose, etc.) of poplar are partially degraded during the extraction process, which is consistent with the trend of chemical composition changes of pine during the extraction process, but the changing trend of density is opposite. The density of poplar wood after extraction was increased $0.199 \mathrm{~g} / \mathrm{cm}^{3}$ (as shown in Table 5), and this contradicts the conclusions of the cited authors. The main reason is that the volumetric shrinkage of the poplar wood after extraction, which reduces the cell wall pores (Fig. 5B). Therefore, the density was increased.

Table 5. Mechanical Properties of Poplar Wood Before and After Extraction

\begin{tabular}{|c|c|c|l|c|c|c|c|}
\hline Group & $\begin{array}{c}\text { Density } \\
\left(\mathrm{g} / \mathrm{cm}^{3}\right)\end{array}$ & \multicolumn{2}{|c|}{$\begin{array}{c}\text { Bending Strength } \\
(\mathrm{N} \cdot \mathrm{m} / \mathrm{Kg})\end{array}$} & \multicolumn{2}{c|}{$\begin{array}{c}\text { Tensile Strength } \\
(\mathrm{N} \cdot \mathrm{m} / \mathrm{Kg})\end{array}$} & \multicolumn{2}{c|}{$\begin{array}{c}\text { Impact Strength } \\
(\mathrm{N} \cdot \mathrm{m} / \mathrm{Kg})\end{array}$} \\
\hline & & Average & $\begin{array}{l}\text { Variable } \\
\text { Quantity }\end{array}$ & Average & $\begin{array}{l}\text { Variable } \\
\text { Quantity }\end{array}$ & Average & $\begin{array}{l}\text { Variable } \\
\text { Quantity }\end{array}$ \\
\hline Poplar Wood & 0.332 & 228.67 & & 49.31 & & 57.11 & \\
\hline $\begin{array}{c}\text { Extraction } \\
\text { Poplar Wood }\end{array}$ & 0.531 & 271.28 & 42.61 & 54.61 & 5.3 & 39.42 & -17.69 \\
\hline
\end{tabular}

In addition, the bending strength and tensile strength of poplar after extraction were increased by 42.61 and $5.3 \mathrm{~N} \cdot \mathrm{m} / \mathrm{Kg}$, respectively. Obviously, the main reason for the increase in bending strength and tensile strength was the increase in density (Missanjo and 
Matsumura 2016). The impact strength of poplar after extraction was reduced 17.69 $\mathrm{N} \cdot \mathrm{m} / \mathrm{Kg}$. The width of crystal region and crystallinity of poplar were increased after extraction (as shown in Table 3), which results in increased cellulose-cellulose bonding. Therefore, when the relatively flexible hemicellulose-cellulose-hemicellulose bonding is replaced by a more rigid cellulose-cellulose bonding, the flexibility of the wood is decreased (Kocaefe et al. 2008).

\section{CONCLUSIONS}

1. The extractives, cellulose, lignin, and hemicellulose all exhibited different degrees of degradation under the action of extraction solvents.

2. With the dissolution of extractives, new peaks appeared at $3.06 \mathrm{~nm}$ and $5.6 \mathrm{~nm}$, and a large number of mesopores and macropores were produced. The numbers of mesopores were significantly reduced due to the volume shrinkage of poplar wood after extraction, but the number of macropores increased.

3. With the dissolution of extractives, the crystal structure of wood was affected. After extraction treatment, the crystallinity of poplar and pine increased $12.4 \%$ and $5.7 \%$, respectively. Nevertheless, the crystal form was not changed.

4. The change of mechanical properties of wood was mainly caused by the change of internal structure. Therefore, the extractives indirectly affected the mechanical properties of wood through its influence on the wood structure.

\section{ACKNOWLEDGMENTS}

This work was supported by the National Natural Science Foundation of China under grant No. 31860187.

\section{REFERENCES CITED}

Arganbright, D. G. (1971). "Influence of extractives on bending strength of redwood (Sequoia sempervirens)," Wood Fiber 2(4), 367-372.

Bali, G., Meng, X., Deneff, J. I., Sun, Q., and Ragauskas, A. J. (2015). "The effect of alkaline pretreatment methods on cellulose structure and accessibility," ChemSusChem 8(2), 275-279. DOI: 10.1002/cssc.201402752

Chaouch, M., Dumarcay, S., Pétrissans, A., Pétrissans, M., and Gerardin, P. (2013). "Effect of heat treatment intensity on some conferred properties of different european softwood and hardwood species," Wood Science and Technology 47(4), 663-673. DOI: $10.1007 / \mathrm{s} 00226-013-0533-\mathrm{z}$

Dandrea, C., Farina, A., Comelli, D., Pifferi, A., Taroni, P., Valentini, G., and Kienle, A. (2008). "Time-resolved optical spectroscopy of wood," Applied Spectroscopy 62(5), 569-574. DOI: 10.1366/000370208784344424 
Ding, Y., Ezekoye, O. A., Lu, S., Wang, C., and Zhou, R. (2017). "Comparative pyrolysis behaviors and reaction mechanisms of hardwood and softwood," Energy Conversion and Management 132, 102-109. DOI: 10.1016/j.enconman.2016.11.016

Doczekalska, B., and Zborowska, M. (2010). "Wood chemical composition of selected fast growing species treated with naoh part ii:non-structural substances," Wood Research 55(3), 83-92.

Durmaz, E., Ucuncu, T., Karamanoglu, M., and Kaymakci, A. (2019). "Effects of heat treatment on some characteristics of scots pine (Pinus sylvestris L.) wood," BioResources 14(4), 9531-9543. DOI: 10.15376/biores.14.4.9531-9543

Fang, L., Xiong, X. Q., Wang, X. H., Chen, X., and Mo, X. F. (2017). "Effects of surface modification methods on mechanical and interfacial properties of high-density polyethylene-bonded wood veneer composites," Journal of Wood Science 63(1):6573. DOI: $10.1007 / \mathrm{s} 10086-016-1589-9$

Fatrawana, A., Maulana, S., Nawawi, D. S., Sari, R. K., Hidayat, W., and Park, S. H., (2019). "Changes in chemical components of steam-treated betung bamboo strands and their effects on the physical and mechanical properties of bamboo-oriented strand boards," European Journal of Wood and Wood Products 77(5), 731-739. DOI: 10.1007/s00107-019-01426-7

Golpayegani, A. S., Brémaud, I., Gril, J., Thevenon, M. F., Arnould, O., and Pourtahmasi, K. (2012). "Effect of extractions on dynamic mechanical properties of white mulberry (Morus alba)," Journal of Wood Science 58(2), 153-162. DOI: 10.1007/s10086-011-1225-7

Grabner, M., Müller, U., Gierlinger, N., and Wimmer, R. (2005). "Effects of heartwood extractives on mechanical properties of larch," Iawa Journal 26(2), 211-220. DOI: $10.1163 / 22941932-90000113$

He, Z. B., Wang, Z. Y., Qu, L. J., Qian, J., Yi, S. L. (2019). “Gaseous decomposition products from wood degradation via thermogravimetric and Fourier transform infrared analysis during thermal modification of beech and pine woods," BioResources 14(3), 6883-6894. DOI: 10.15376/biores.14.3.6883-6894

Herliyana, E. N., Nandika, D., Sudirman, L. I., and Witarto, A. B. (2008). "Biodegradation of sengon sawn substrate by Pleurotus fungi from Bogor," Masyarakat Peneliti Kayu Indonesia 6(2), 75-83.

Hernandez, R. E. (2007). "Influence of accessory substances, wood density and interlocked grain on the compressive properties of hardwoods," Wood Science and Technology 41(3), 249-265. DOI: 10.1007/s00226-006-0114-5

Hu, Z., Chen, J., Jiang, S., Liu, Z., Ge, S., and Zhang, Z. (2020). "Chemical components and functions of Taxus chinensis extract," Journal of King Saud University - Science 32(2), 1562-1568. DOI: 10.1016/j.jksus.2019.12.012

Huang, A., Zhao, Q., Liu, J. L., Fei, B. H., and Sun, S. Q. (2008). "Distinction of three wood species by Fourier transform infrared spectroscopy and two-dimensional correlation IR spectroscopy," Journal of Molecular Structure 883-884, 160-166. DOI: 10.1016/j.molstruc.2007.11.061

Ishimaru, K., Hata, T., Bronsveld, P., Meier, D., and Imamura, Y. (2007). "Spectroscopic analysis of carbonization behavior of wood, cellulose and lignin," Journal of Materials Science 42(1), 122-129. DOI: 10.1007/s10853-006-1042-3

Kim, Y. M., Han, T. U., Hwang, B. A., Lee, B., Lee, H. W., Park, Y. K., and Kim, M. (2016). "Pyrolysis kinetics and product properties of softwoods, hardwoods, and the 
nut shell of softwood," The Korean journal of chemical engineering 33(8), 23502358. DOI: $10.1007 / \mathrm{s} 11814-016-0142-2$

Kocaefe, D., Poncsak, S., and Boluk, Y. (2008). "Effect of thermal treatment on the chemical composition and mechanical properties of birch and aspen," BioResources 3(2), 517-537. DOI: 10.15376/biores.3.2.517-537

Li, R. R., Xu, W., Wang, C. G., Zhang, S. B., and Song, W. (2018). "Optimization for the liquefaction of moso bamboo in phenol using response surface methodology," Wood and Fiber Science 50(2), 220-227. DOI: 10.22382/wfs-2018-022

Li, R. R., Xu, W., Wang, X. D., and Wang, C. G. (2018). "Modeling and predicting of the color changes of wood surface during $\mathrm{CO}_{2}$ laser modification," Journal of Cleaner Production 183:818-823. DOI: 10.1016/j.jclepro.2018.02.194

Li, Z., Qin, M., Xu, C., and Chen, X. (2013). "Hot water extraction of hemicelluloses from aspen wood chips of different sizes," BioResources 8(4), 5690-5700. DOI: 10.15376/biores.8.4.5690-5700

Ma, X., Zheng, X., Lin, L., Chen, L., Survase, S., and Huang, L. (2015). "Evaluating effects of benzene-ethanol extraction on molecular weight of lignin isolated from pretreated bamboo substrate," Wood Science and Technology 49(5), 945-955. DOI: 10.1007/s00226-015-0735-7

Ma, X. J., Cao, S. L., Yang, X. F., Lin, L., Chen, L. H., and Huang, L. L. (2014). “Lignin removal and benzene-alcohol extraction effects on lignin measurements of the hydrothermal pretreated bamboo substrate," Bioresource Technology 151, 244-248. DOI: 10.1016/j.biortech.2013.10.078.

Missanjo, E., and Matsumura, J. (2016). "Wood density and mechanical properties of Pinus kesiya Royle ex Gordon in Malawi," Forests 7(7), 135. DOI: 10.3390/f7070135

Pandey, K. (2005). "A note on the influence of extractives on the photo-discoloration and photo-degradation of wood," Polymer Degradation and Stability 87(2), 375-379. DOI: $10.1016 /$ j.polymdegradstab.2004.09.007

Paredes, J. J., Shaler, S., Howell, C., and Jakes, J. (2017). "Influence of hot water extraction on cell wall and OSB strand mechanics," Wood Science and Technology 51(6), 1307-1319. DOI: 10.1007/s00226-017-0951-4.

Patterson, A. L. (1939) "The Scherrer formula for X-ray particle size determination," Physical Review 56(10), 978-982. DOI: 10.1103/PhysRev.56.978

Pei, J. C., Ping, Q. W., Tang, A. M., and Li X. P. (2017). Plant Fiber Chemistry, Fourth Ed.," Beijing: China Light Industry Press.

Peng, W. X., Li, D. L., and Zhang, M. L., Ge, S. B., Mo, B., Li, S. S., and Ohkoshi, M. (2017). "Characteristics of antibacterial molecular activities in poplar wood extractives," Saudi Journal of Biological Sciences 24, 399-404. DOI: 10.1016/j.sjbs.2015.10.026

Rigual, V., Santos, T. M., Domínguez J. C., Alonso, M. V., Olient, V., and Rodriguez, F. (2018). "Evaluation of hardwood and softwood fractionation using autohydrolysis and ionic liquid microwave pretreatment," Biomass and Bioenergy 117, 190-197. DOI: 10.1016/j.biombioe.2018.07.014

Roffael, E. (2016). "Significance of wood extractives for wood bonding," Applied Microbiology and Biotechnology 100(4), 1589-1596. DOI: 10.1007/s00253-0157207-8 
Sameni, J., Krigstin, S., and Sain, M. (2017). "Solubility of lignin and acetylated lignin in organic solvents," BioResources 12(1), 1548-1565. DOI: 10.15376/biores.12.1.15481565

Segal, L., Creely, J. J., Martin, A. E., and Conrad, C. M. (1959). “An empirical method for estimating the degree of crystallinity of native cellulose using the X-ray diffractometer," Textile Research Journal 29(10), 786-794. DOI: 10.1177/004051755902901003

Sheshmani, S., Ashori, A., and Farhani, F. (2012). "Effect of extractives on the performance properties of wood flour-polypropylene composites," Journal of Applied Polymer Science 123(3), 1563-1567. DOI: 10.1002/app.34745

Shi, H. Q., Zhao, M. F., Li, C., Sheng, X. R., Yang, Q., Li, N., and Niu, M. H. (2019). "Surface sediments formation during auto-hydrolysis and its effects on the benzenealcohol extractive, absorbability and chemical pulping properties of hydrolyzed acacia wood chips," Bioresource Technology 289. DOI: 10.1016/j.biortech.2019.121604.

Sing, K. S. (1985). "Reporting physisorption data for gas/solid systems with special reference to the determination of surface area and porosity (Recommendations 1984)," Pure and Applied Chemistry 57(4), 603-619. DOI: $10.1351 /$ pac198557040603

Sugii, S., Fujimoto, T., Tsutsumi, H., Inagaki, T., and Tsuchikawa, S. (2017). "Dynamic behavior of wood chemical components under drying process measured by near infrared spectroscopy," Journal of Near Infrared Spectroscopy 25(6), 400-406. DOI: $10.1177 / 0967033517733379$

Tao, F., Liu, Y., and An, N. (2010). "On the necessity of organic solvent extraction for carbon isotopic analysis of $\alpha$-cellulose: Implications for environmental reconstructions," International Journal of Environmental Analytical Chemistry 90(8), 605-619. DOI: 10.1080/03067310903410949

TAPPI T204 om-97 (1997). "Solvent extractives of wood and pulp," TAPPI Press, Atlanta, GA, USA.

TAPPI T207 om-99 (1999). "Water solubility of wood and pulp," TAPPI Press, Atlanta, GA, USA.

TAPPI T212 om-12 (2012). “One percent sodium hydroxide solubility of wood and pulp," TAPPI Press, Atlanta, GA, USA.

TAPPI T222 om-11 (2011). “Acid-insoluble lignin in wood and pulp," TAPPI Press, Atlanta, GA, USA.

TAPPI T223 om-10 (2010). "Pentosans in wood and pulp," TAPPI Press, Atlanta, GA, USA.

Ufodike, C. O., Eze, V. O., Ahmed, M. F., Oluwalowo, A., Park, J. G., Liang, Z., and Wang, H. (2020). "Investigation of molecular and supramolecular assemblies of cellulose and lignin of lignocellulosic materials by spectroscopy and thermal analysis," International Journal of Biological Macromolecules 146, 916-921. DOI: 10.1016/j.ijbiomac.2019.09.214

Valette, N., Perrot, T., Sormani, R., Gelhaye, E., and Morelrouhier, M. (2017). "Antifungal activities of wood extractives," Fungal Biology Reviews 31(3), 113-123. DOI: 10.1016/j.fbr.2017.01.002

Vital, B. R., Lucia, R. M., and Euclides, R. F. (1983). "Effect of heating on some properties of Eucalyptus saligna wood," Revista Árvore 7(2), 136-146. 
Wang, X., Li, Y., Deng, Y., Yu, W., Xie, X., and Wang, S. (2016). “Contributions of basic chemical components to the mechanical behavior of wood fiber cell walls as evaluated by nanoindentation," BioResources 11(3), 6026-6039. DOI: 10.15376/biores.11.3.6026-6039

Wetzig, M., Heldstab, C., Tauscher, T., and Niemz, P. (2011). "Ermittlung ausgewählter mechanischer Kennwerte thermisch modifizierter Buche (Determination of selected mechanical parameters of thermally modified beech)," Bauphysik 33(6), 366-373. DOI: 10.1002/bapi.201110794.

Yang, Z., Liu, Y. N., Lv, B., and Xie, X. Q. (2012). "Rapid classification of softwood and hardwood by near infrared spectroscopy of wood tangential section," Applied Mechanics and Materials 157-158, 1624-1627. DOI:

10.4028/www.scientific.net/AMM.157-158.1624

Article submitted: July 6, 2020; Peer review completed: August 29, 2020; Revised version received and accepted: September 19, 2020; Published: September 25, 2020.

DOI: 10.15376/biores.15.4.8631-8647 